\title{
Trajectory of Water- and Fat-Soluble Dyes in the Grass-Cutting ant Atta capiguara (Hymenoptera, Formicidae): Evaluation of Infrabuccal Cavity, Post-Pharyngeal Glands and Gaster
}

by

Luiz Carlos Forti ${ }^{1}$, Marcílio de Souza Silva ${ }^{{ }^{*}}$, Ricardo Toshio Fujihara ${ }^{1}$, Nádia Caldato ${ }^{1} \&$ Marise Grecca Garcia ${ }^{1}$

\begin{abstract}
The diet of leaf-cutting ants is based on cultivation of their symbiotic fungus, whose successful cultivation depends on the task of incorporation and handling of vegetable substrate. This task may cause the workers to be contaminated with toxic substances and thus decrease the survival of the colony. The objective of this study was to analyze the contamination of workers of Atta capiguara as well as the dissemination trajectory of water- and fat-soluble substances. Four colonies received non-toxic baits containing water-soluble dye Rhodamine-B and three, non-toxic baits with fat-soluble dye Sudan III. The dye Rhodamine-B stained the gaster in $40.31 \%$ of workers and showed no significant difference among castes. The Sudan III stained the infrabuccal cavity in $35.41 \%$, post-pharyngeal glands of $24.22 \%$ and gaster in only $8.44 \%$ of the workers, with no significant difference among the castes. The watersoluble dye was spread in the body of workers through the digestive system while fat-soluble dye was diverted to the post-pharyngeal glands.

Keywords: digestive system; glands; leaf-cutting ants; manipulation; toxic baits

\section{INTRODUCTION}

Social insects, such as leaf-cutting ants, present a division of labor and complex behavioral activities, including foraging (Hölldobler \& Wilson 1990). Their principal food source comes from the cultivation of the symbiotic fungus Leucoagaricus gongylophorus with vegetal substrate (Silva et al. 2003; Santos et al. 2006). However, larger workers obtain part of their diet

${ }^{1}$ Laboratório de Insetos Sociais-Praga, Defesa Fitossanitária, FCA/UNESP, Fazenda Exp. Lageado, Rua José Barbosa de Barros 1780, Zip Code 18610-307, PO Box 237, Botucatu, SP, Brazil.

*Corresponding author: agromss@hotmail.com
\end{abstract}


from liquids released during the cutting of leaves (Peregrine \& Mudd 1975; Quinlan \& Cherrett 1978; Forti \& Andrade 1999). In practical terms, the incorporation of vegetal substrate into the fungus garden is closely related to the contamination of workers by insecticides formulated into granulated bait (Andrade et al. 2002).

This knowledge has generated a series of studies in the area of chemical control ofleaf-cutting ants, but most are experiments with insecticides that aim to elucidate the dynamic of workers contamination (Echols 1966; Andrade 2002; Pagnocca et al. 2006; Santos et al. 2006; Nagamoto et al. 2007).

According to Peregrine and Cherrett (1976), many studies are performed that seek to discover different chemical substances with formicidal activity, but few focus on obtainingknowledge of their action mechanism. To this end, dyes are utilized as a tool to demonstrate not only the ingestion of plant sap by ants but also the dispersal of insecticides within their organism (Peregrine et al. 1972; Bueno et al. 2001; Forti et al. 2007).

Furthermore, it should be emphasized that the digestive system of adult ants, when compared to that of other insects, presents some adaptations. Anterior to the mouth opening, just after the glossa, is found the infrabuccal cavity, in which the solid material is retained by a filter of small bristles, where only the liquid or semi-solid foods pass to the proventriculus. The latter regulates the passage of food from the crop to the ventriculus, where digestion then occurs (Fowler et al. 1991; Chapman 1998; Jesus \& Bueno 2007).

At the end of the pharynx, near its transition with the esophagus, the ducts of the post-pharyngeal glands open dorsally, as found in Formicidae and solitary wasps (Delage-Darchen 1976; Strohm et al. 2007; Bagnères \& Blomquist 2010). According to some authors, theseglands are associated with the synthesis of lipids (Peregrine et al. 1972; Gama 1985; Eelen 2006) and the accumulation of cuticular hydrocarbons duringontogenesis, important in the regulation and recognition of nest partners (Soroker et al. 1994; Bagnères \& Blomquist 2010). Nevertheless, these glands remain little studied.

The crop, although considered underdeveloped in the genus Atta, is responsible for the storage of liquids (Paul \& Roces 2003). Nevertheless, some studies suggest the absence of trophalaxis among its workers, who did not present sharing of stored food (Andrade 1997; Andrade et al. 2002; Bueno 2005). 
The singular morphological characteristics of Formicidae and the differentiated behavioral repertoire of grass-cutting ants, which process less substrate for incorporation into the symbiotic fungus, are factors to be evaluated in the dispersal of insecticides and supply of informations on the post-pharyngeal glands, whose functions still have not been completely elucidated. Therefore, the present study aimed to analyze the contamination frequency of workers of $A$. capiguara, as well as the dissemination trajectory of water- and fatsoluble substances (in the form of dyes), through their digestive system and post-pharyngeal glands.

\section{MATERIAL AND METHODS}

\section{Collection of $A$. capiguara colonies}

Young colonies of $A$. capiguara were collected from pasture areas in Botucatu, SP, Brazil (23 $\left.06^{\prime} 08^{\prime \prime} \mathrm{S}, 48^{\circ} 25^{\prime} 28^{\prime \prime} \mathrm{W}\right)$ and transported to the Laboratório de Insetos Sociais-Praga, FCA/UNESP, Botucatu.

They were raised in a closed system at a temperature of $24^{\circ} \mathrm{C} \pm 1$ and relative air humidity of $70 \% \pm 1$, utilizing transparent plastic pots $(1 \mathrm{~cm}$ of plaster at the bottom) to maintain the humidity of the colony. The vegetal materials used as substrate were leaves of sugarcane (Saccharum officinarum) or tifton grass (Cynodon spp.). Before performing the experiments, the colonies were maintained without receiving leaves for 48 hours.

\section{Preparation and offering of baits}

The baits containing water-soluble dye were prepared with $90 \%$ sugarcane leaf powder, $6 \%$ water and $4 \%$ Rhodamine-B dye (Vetec Química Fina). For the baits with fat-soluble dye, the proportion was $90 \%$ sugarcane leaf powder, 6\% soy oil and $4 \%$ Sudan III (Vetec Química Fina).

After mixing, the ingredients were placed in disposable polyethylene bags with a small hole in the nozzle $(2.5 \mathrm{~mm} \varnothing)$, thereby formulating the bait filets. After 24 hours of drying at room temperature, the filets were cut into pellets $0.5 \mathrm{~cm}$ in length.

Four colonies received baits containing the water-soluble dye Rhodamine-B whereas three received baits with the fat-soluble Sudan III dye, at the dose of $0.5 \mathrm{~g} /$ colony. It should be emphasized that neither contained the active ingredient and that, after the baits had been offered for 30 hours, the fungus garden and the workers were stored in a freezer. 


\section{Evaluation of dye digestion}

The workers of each colony were separated into three castes, according to the width of the cephalic capsule: gardeners $(<1.4 \mathrm{~mm})$, generalists $(1.4$ $-2.1 \mathrm{~mm})$ and foragers $(>2.1 \mathrm{~mm})$. The colonies that received baits with Rhodamine-B were evaluated only for staining of the gaster. With the aid of forceps, this was compressed on dried ribbons of pig intestine on account of their protein content, which enabled easy impregnation of the dye. After this procedure, the ribbons were placed under ultraviolet light, permitting a count of the number de individuals marked with the dye (Forti et al.2007).

The workers of the colonies that received Sudan III baits were dissected stereoscopically to observe the infrabuccal cavity (IC), post-pharyngealglands (PPG) and the gaster.

\section{Data analysis}

After the period during which baits were offered to the workers (30 hours), these individuals were collected and counted. Subsequently, the absolute frequency data of stained and unstained anatomical structures were submitted to the Chi-Square test $\left(\chi^{2}\right)$, at $5 \%$ significance level, utilizing the program BioEstat 5.0 (Ayres et al. 2007). When the test revealed significance, a contingency table and partition analysis were completed to assess whether the castes differed as to the dye utilized (water- or fat-soluble).

\section{RESULTS}

When the dye Rhodamine-B was utilized, the proportion of $A$. capiguara workers that presented stained versus unstained gaster structures (crop, ventriculus and rectum) was independent of the caste, that is, there was no significant difference among these types (Table 1).

Of the total of 583 workers analyzed, $40.31 \%$ had a stained gaster, revealing that the water-soluble substance Rhodamine-B was disseminated through the digestive tract of the workers. Thus, it is supposed that substances toxic to ants such as some insecticides, for example, when water-soluble, can also contaminate the same by digestive pathways. Taking into consideration the relative frequency of the data presented in Table 1, the results show that $39.19 \%$ of the foragers had a stained gaster, the same occurring to $44.19 \%$ of generalists and $38.10 \%$ of gardeners. According to Forti et al. (2007), the 
Table 1-Proportion of $A$. capiguara workers by caste with gaster stained and unstained after application of baits with Rhodamine-B dye. ns: Not significant by Chi-Square test $(\mathrm{P}<0.05)$.

\begin{tabular}{lllllll}
\hline \hline \multirow{2}{*}{ Structure } & \multirow{2}{*}{ Proportion } & \multicolumn{5}{c}{ Caste } \\
& & Foragers & Generalists & Gardeners & $\chi^{2}$ & $\boldsymbol{P}$ \\
\hline \multirow{2}{*}{ Gaster } & Stained & 87 & 76 & 72 & $1.00^{\text {ns }}$ & 0.3159 \\
& Unstained & 135 & 96 & 117 & $0.56^{\text {ns }}$ & 0.4505 \\
General & - & - & - & - & $1.57^{\text {ns }}$ & 0.4549 \\
\hline \hline
\end{tabular}

Table 2 - Proportion of $A$. capiguara workers by caste with anatomical structures stained and unstained after application of baits with Sudan III dye. IC: infrabuccal cavity; PPG: post-pharyngeal glands.

\begin{tabular}{|c|c|c|c|c|c|c|}
\hline \multirow{2}{*}{ Structure } & \multirow{2}{*}{ Proportion } & \multicolumn{3}{|c|}{ Castes } & \multirow[b]{2}{*}{$\chi^{2}$} & \multirow{2}{*}{$P$} \\
\hline & & Foragers & Generalists & Gardeners & & \\
\hline \multirow{2}{*}{ IC } & Stained & 42 & 51 & 100 & $3.22^{\mathrm{ns}}$ & 0.0726 \\
\hline & Unstained & $122 \mathrm{ab}$ & $93 a$ & $137 \mathrm{~b}$ & $8.43^{\circ}$ & 0.0037 \\
\hline General & - & - & - & - & $11.65^{\circ}$ & 0.0029 \\
\hline \multirow{2}{*}{ PPG } & Stained & 32 & 35 & 65 & $0.95^{\mathrm{ns}}$ & 0.3272 \\
\hline & Unstained & 132 & 109 & 172 & $2.34^{\mathrm{ns}}$ & 0.1254 \\
\hline General & - & - & - & - & $3.30^{\mathrm{ns}}$ & 0.1913 \\
\hline \multirow{2}{*}{ Gaster } & Stained & 9 & 12 & 25 & $0.80^{\mathrm{ns}}$ & 0.3701 \\
\hline & Unstained & 155 & 132 & 212 & $2.41^{\mathrm{ns}}$ & 0.1204 \\
\hline General & - & - & - & - & $3.21^{\mathrm{ns}}$ & 0.2004 \\
\hline
\end{tabular}

"Frequencies followed by distinct letters on the line differ with each other by the Chi-Square test $(\mathrm{P}<0.05)$. ns: Not significant by the Chi-Square test $(\mathrm{P}<0.05)$.

Table 3 - Absolute and relative frequency of $A$. capiguara workers presenting stained PPG and gaster, among those with IC stained by Sudan III. IC: infrabuccal cavity; PPG: post-pharyngeal glands; AF: absolute frequency; RF: relative frequency.

\begin{tabular}{llllllll}
\hline \hline \multirow{2}{*}{ Caste (IC stained) } & \multirow{2}{*}{$\mathrm{N}$} & \multicolumn{2}{c}{ PPG stained } & \multicolumn{2}{c}{ Gaster stained } & \multicolumn{2}{c}{ Only IC stained } \\
& & $\mathrm{AF}$ & $\mathrm{RF}(\%)$ & $\mathrm{AF}$ & $\mathrm{RF}(\%)$ & $\mathrm{AF}$ & $\mathrm{RF}(\%)$ \\
\hline Foragers & 42 & 32 & 76.19 & 9 & 21.43 & 1 & 2.38 \\
Generalists & 51 & 35 & 68.63 & 12 & 23.53 & 4 & 7.84 \\
Gardeners & 100 & 65 & 65.00 & 25 & 25.00 & 10 & 10.00 \\
Total & 193 & 132 & 68.39 & 46 & 23.84 & 15 & 7.77 \\
\hline \hline
\end{tabular}

highest level of contamination (about $50 \%$ ) occurs in the first 24 hours in all sizes of workers, thus, justifying our assessment during 30 hours.

In relation to the trajectory of Sudan III fat-soluble dye, out of a total of 545 workers dissected, only those with unstained IC presented a significant difference (Table 2). Of the 164 foragers dissected, $25.61 \%$ presented stained IC, 19.51\% PPG and only 5.49\%, a stained gaster. These percentages were obtained in relation to the total number of workers, since not all that had 
stained IC also presented stained PPG, which also occurred with the gaster. Among the generalists and gardeners, the same calculation was performed.

The total data on stained workers demonstrate that not all individuals came into contact with the dye, or that only a percentage of them were contaminated. Thus, the IC was most frequently stained structure among the castes (25.61\%), with gardeners representing the highest proportion of stained individuals (42.19\%). This category also presented the highest percentage of workers with stained PPG (27.43\%) and gaster (10.55\%). Analysis of the workers that had stained IC also reveals which individuals had PPG and gaster stained (Table 3).

The workers with IC stained by Sudan III also presented stained PPG, suggesting that the fat-soluble dye was disseminated by PPG in the majority of workers that had come into contact with this dye. This structure must also be the contamination route of other fat-soluble substances that can be used as insecticides.

Probably, in the workers that presented only stained IC, which were the minority, the dye had not yet disseminated to the PPG and/or to the gaster, independently of the caste analyzed, due to its high solubility in lipids, which by ingesting the dye tended to present more stained PPG.

\section{DISCUSSION}

In relation to Rhodamine- $\mathrm{B}$, individuals were found with stained gaster in the three castes of $A$. capiguara workers, but without significant difference among them. Water-soluble substances dissolved in plant sap can be absorbed by the digestive tract, as observed by Andrade (1997) when studying the ingestion of Rhodamine-B by workers of Atta sexdens rubropilosa, by means of vegetal sap previously stained with this substance. This study verified that more than $50 \%$ of the workers evaluated had a stained gaster, in other words, a contaminated digestive system, but the absorption of dye was greater among the gardeners, who present greater specialization in licking or cutting stained leaf fragments, than among the foragers, due to the fact that in the act of cutting, the substrate absorbs less sap.

Although the objective of Andrade (1997) had been to assess the ingestion of the vegetal sap utilized as substrate for the symbiotic fungus by the workers, the response found may be compared to that obtained in the present study, 
since there was no significant difference among the castes. A contamination difference among the $A$. capiguara castes could not have been evidenced by the fact that this species processes less substrate and by having used bait, which is a solid substrate in contrast to the liquid sap substrate.

Despite this, other studies have also revealed staining in the gaster after the use of Rhodamine-B such as that of Forti et al. (2007), who analyzed the dispersal of the active formicidal ingredient sulfluramide, jointly with Rhodamine-B as a tracer, and found $66.5 \%$ of $A$. sexdens rubropilosa workers stained in laboratory colonies and $40.9 \%$ in field colonies. Bueno et al.(2001), also observed gaster staining among workers of $A$. sexdens by Rhodamine-B, but concluded that the allogroming and self-grooming performed by the workers is responsible for displacing the dye.

In relation to dispersal of fat-soluble substances, such as Sudan III dye, less than $50 \%$ of the workers were found to be contaminated in similar proportions among the three castes, as occurred with the employment of water-soluble dye. These results corroborate those reported by Echols (1966), Peregrine $e t$ al. (1972) and Andrade (2002).

The percentage of $A$. capiguara workers with a gaster stained by Sudan III was much smaller in relation to the other structures, in agreement with Andrade (2002), who studied workers of Acromyrmex subterraneus treated with baits without the active principle and stained with Sudan Black (fatsoluble). It was observed that $27.9 \%$ of the worker presented stained PPG and IC while only $9.1 \%$ possessed stained crop and ventriculus. It is probable that Sudan III dye requires a longer exposure of substrate stained by grass-cutting workers due to lesser frequency of manipulation.

Another reason may be related to the quantity of lipid substances present in the bait and its ingestion, given that the probability of PPG staining is proportional to the quantity of lipids present in these glands (Jesus \& Bueno 2007).

According to Vinson et al.(1980), the destination oflipid compounds in the digestive system is the PPG lumen, thus explaining the low presence of Sudan III dye in workers gaster. Among such species as Tapinoma melanocephalum, Monomorium pharaonis, Linepithema humile and Paratrechina fulva, if the quantity of lipids ingested by the workers is large, this substance is stored in both the PPG and crop of the individuals. However, these lipids are not 
transported to the ventriculus and after some time return via the esophagus until they reach the PPG (Jesus \& Bueno 2007).

Thus, water-soluble substances are disseminated in the workers organism through the digestive system whereas fat-soluble ones are directed to such glands as the PPG. What varies is the percentage of individuals contaminated due the substrate preference and manipulation time, according to the castes of each species.

\section{ACKNOWLEDGMENTS}

The authors are grateful to the School of Agronomy (FCA/UNESP) for making this research possible and to "CNPq - Conselho Nacional de Desenvolvimento Científico e Tecnológico" for support to the first author (grant 150137/2004-4).

\section{REFERENCES}

Andrade, A.P.P. 1997. Comportamento forrageiro e aprendizado de operárias de Atta sexdens rubropilosa Forel, 1908 (Hymenoptera, Formicidae) em condiçóes de campo e laboratório. MSc. Thesis, Universidade Estadual Paulista, Botucatu, São Paulo, Brazil (unpublished). 100.

Andrade, A.P.P. 2002. Biologia e Taxonomia comparadas das subespécies de Acromyrmex subterraneus Forel, 1893 (Hymenoptera, Formicidae) e contaminação das operárias por iscas tóxicas. PhD. Thesis, Universidade Estadual Paulista, Botucatu, São Paulo, Brazil (unpublished). 168.

Andrade, A.P.P., L.C. Forti, A.A. Moreira, M.A.C. Boaretto, V.M. Ramos \& C.A.O. Matos. 2002. Behavior of Atta sexdens rubropilosa (Hymenoptera: Formicidae) workers during the preparation of the leaf substrate for symbiont fungus culture. Sociobiology 40: $1-14$.

Ayres, M., J.R.M. Ayres, D.L. Ayres \& A.S. Santos. 2007. BioEstat 5.0: aplicações estatísticas nas áreas das ciências biológicas e médicas. Instituto de Desenvolvimento Sustentável Mamirauá. Belém, PA.

Bagnères, A.G. \& G.J. Blomquist. 2010. Site of synthesis, mechanism of transport and selective deposition of hydrocarbons. pp. 75-99. In: Insect Hydrocarbons G.J. Blomquist \& A.G. Bagnères (eds.), University of Nevada, Reno.

Bueno, O.C. 2005. Filtro infrabucal e glândula pós-faríngea da saúva-limão Atta sexdens rubropilosa Forel (Hymenoptera: Formicidae). Rio Claro. Associate Professor Thesis, Universidade Estadual Paulista, Botucatu, São Paulo, Brazil (unpublished). 107.

Bueno, O.C., D. Fresneau, O.M. Schineider, C. Silveira \& F.C. Bueno. 2001. Fluxo de corantes hidrossolúveis e lipossolúveis no trato digestivo de operárias de Atta sexdens L. 1758 (Hymenoptera: Formicidae). In: Anais do XV Encontro de Mirmecologia, 
Londrina, PR, Brasil.

Chapman, R.F. 1998. The Insects: Structure and function. Cambridge University Press, Cambridge. $770 \mathrm{p}$.

Delage-Darchen, B. 1976. Les glandes post-pharyngiennes des fourmis. Connaissances actuelles sur leur structure, leur fonctinnement, leur rôle. Annals of Biology 15(1-2): 63-76.

Echols, H.W. 1966. Assimilation and transfer of mirex in colonies of Texas leaf-cutting ants. Journal of Economic Entomology 59: 1336-1338.

Eelen, D., L.W. Børgesen \& J. Billen 2006. Functional morphology of the postpharyngeal gland of queens and workers of the ant Monomorium pharaonis (L.). Acta Zoologica 87(2): 101-111.

Forti,L.C. \& A.P.P.Andrade.1999. Ingestão de líquidos por Attasexdens (L.) (Hymenoptera, Formicidae) durante a atividade forrageira e na preparação do substrato em condições de laboratório. Naturalia 24: 61-63.

Forti, L.C., D.R. Pretto, N.S. Nagamoto, C.R. Padovani, R.S. Camargo \& A.P.P. Andrade. 2007. Dispersal of the delayed action insecticide Sulfluramid in colonies of the leafcutting ant Atta sexdens rubropilosa (Hymenoptera: Formicidae). Sociobiology 50(3): 1149-1163.

Fowler, H.G., L.C. Forti, C.R.F. Brandão, J.H.C. Delabie \& H.L. Vasconcelos. 1991. Ecologia nutricional de formigas. pp. 131-223. In: Panizzi, A. R. \& J.R.P. Parra (eds.). Ecologia nutricional de insetos e suas aplicações no manejo de pragas. Manole, São Paulo.

Gama, V. 1985. O sistema salivar de Camponotus rufipes (Fabricius, 1775), (Hymenoptera: Formicidae). Revista Brasileira de Biologia 45(3): 317-359.

Hölldobler, B. \& O. E. Wilson. 1990. The Ants. Harvard Univ. Press, Cambridge. 732 p.

Jesus, C.M. \& O.C. Bueno. 2007. Utilização de alimentos em diferentes espécies de formigas. O Biológico 69: 107-110.

Nagamoto,N.S.,L.C.Forti \&C.G. Raetano. 2007.Evaluation of the adequacy of diflubenzuron and dechlorane in toxic for leaf-cutting ants (Hymenoptera: Formicidae) based on formicidal activity. Journal of Pest Science 80(1): 9-13.

Pagnocca, F.C., S.R. Victor, F.C. Bueno, F.R. Crisóstomo, T.C. Castral, J.B. Fernandes, A.G. Corrêa, O.C. Bueno, M. Bacci Jr., M.J.A. Hebling, P.C. Vieira \& M.F.G.F. Silva. 2006. Synthetic amides toxic to the leaf-cutting ant Atta sexdens rubropilosa L. and its symbiotic fungus. Agricultural and Forest Entomology 8(1): 17-23.

Paul, J. \& F. Roces. 2003. Fluid intake rates in ants correlate with their feeding habits. Journal of Insect Physiology 49(4): 347-357.

Peregrine, D.J. \& A. Mudd. 1975. The effect of diet on the composition of the post-pharyngeal glands of Acromyrmex octospinosus (Reich). Insectes Sociaux 21(4): 417-424.

Peregrine, D.J. \& J.M. Cherrett. 1976. Toxicant spread in laboratory colonies of the leafcutting ant. Annals of Applied Biology 84(1): 128-133.

Peregrine, D.J., M.C. Percy \& J.M. Cherrett. 1972. Intake and possible transfer of liquid by post-pharyngeal glands of Atta cephalotes (L.). Entomologia Experimentalis et Applicata 15(2): 248-249. 
Quinlan, R.J. \& J.M. Cherrett. 1978. Studies on the role of the infrabuccal pocket of the leaf-cutting ant Acromyrmex octospinosus (Reich) (Hymenoptera, Formicidae). Insectes Sociaux 25(3): 237-245.

Santos, A.V., B.L. Oliveira \& R.I. Samuels. 2006. Selection of entomopathogenic fungi for use in combination with sub-lethal doses of imidacloprid: perspectives for the control of the leaf-cutting ant Atta sexdens rubropilosa Forel (Hymenoptera: Formicidae). Mycopathologia 163(4): 233-240.

Silva, A., M.J.R. Bacci, C.G. Siqueira, O.C. Bueno, F.C. Pagnocca \& M.J.A. Hebling. 2003. Survival of Atta sexdens on different food sources. Journal of Insect Physiology 49(4): 307-313.

Soroker, V., C. Vienne \& A. Hefetz. 1994. The post-pharyngeal gland as a "Gestalt" organ for nestmate recognition in the ant Cataglyphis niger. Naturwissenschaften 81: 510-513.

Strohm, E., G. Herzner \& W. Goettler. 2007. A 'social' gland in a solitary wasp? The postpharyngeal gland of female European beewolves (Hymenoptera, Crabronidae). Arthropod Structure \& Development 36(2): 113-122.

Vinson, S.B., S.A. Phillips Jr. \& H.J. Williams. 1980. The function of the post-pharyngeal glands of the red imported fire ant, Solenopsis invicta, Buren. Journal of Insect Physiology 26(9): 645-650. 